\title{
Diabetes mellitus and its associated factors among human immunodeficiency virus-infected patients on anti-retroviral therapy in Northeast Ethiopia
}

\author{
Temesgen Fiseha* ${ }^{*}$ and Alemu Gedefie Belete
}

\begin{abstract}
Objective: The aim of this study was to determine the prevalence of diabetes mellitus and its associated factors among human immunodeficiency virus-infected patients on anti-retroviral therapy in Northeast Ethiopia.

Results: A facility based cross-sectional study was conducted among $408 \mathrm{HIV}$-infected adults ( $\geq 18$ years old) attending an ART clinic in Northeast Ethiopia from January to March 30, 2018. The mean ( \pm SD) age of studied patients was $37 \pm 10.3$ years, and 273 (66.9\%) were female. Of the total participants, 36 (8.8\%, 95\% Cl 6.4\% to $11.8 \%)$ had diabetes and 61 (15.0\%, 95\% Cl 11.5\% to 18.6\%) had impaired fasting glucose level (111-125 mg/dl). Only fourteen (3.4\%) participants knew their diabetes status during data collection. In the multivariate analysis, older age (age $>45$ years; $\mathrm{AOR}=3.51,95 \% \mathrm{Cl} 1.52-8.10, P=0.003)$, a family history of diabetes ( $\mathrm{OOR}=6.46,95 \% \mathrm{Cl} 3.36-21.29, P<0.001$ ), duration of $A R T(A O R=2.67,95 \% \mathrm{Cl} 1.16-6.17, P=0.021)$, and hypertension $(A O R=2.62,95 \% \mathrm{Cl} 1.20-5.72, P=0.016)$ were independently associated with increased odds of diabetes. These results highlight the need for regular diabetes screening among HIV-infected patients on ART in order to prevent or reduce disease-related outcomes of these patients in this study setting.
\end{abstract}

Keywords: Diabetes, HIV, Antiretroviral therapy, Ethiopia

\section{Introduction}

Globally, 37 million people are living with the human immunodeficiency virus (HIV). By the end of 2017, 21.7 million people living with HIV were accessing antiretroviral therapy (ART), an increase of 8 million since 2010 [1]. Expansion of access to ART has reduced AIDSrelated mortality and increased life expectancy among people living with HIV in both high- and low-income countries [2-4]. With prolonged survival of persons with HIV, chronic comorbidities including diabetes have emerged as significant causes of morbidity and mortality among these patients with access to ART [5, 6]. Diabetes mellitus is now recognized as an important chronic

\footnotetext{
${ }^{*}$ Correspondence: temafiseha@gmail.com

Department of Clinical Laboratory Science, College of Medicine

and Health Sciences, Wollo University, Dessie, Ethiopia
}

comorbid condition occurring in people living with HIV, and is associated with increased morbidity and mortality [7]. In patients with HIV, diabetes has been shown to be associated with an increased risk for hospitalization, and adverse cardiovascular and renal outcomes, including progression to end-stage renal disease that consequently reduces life expectancy and add to the already high costs of treatment for this population [8-10].

HIV-infected patients on combination ART have a higher prevalence and earlier onset of diabetes when compared with HIV-uninfected individuals [11, 12]. Several risk factors have been shown to contribute to the high prevalence of diabetes in such HIV-infected population, including older age, male sex, family history of diabetes, duration of HIV infection, CD4 count, high body mass index, and hepatitis $\mathrm{C}$ virus ( $\mathrm{HCV})$ co-infection $[7,12,13]$. In addition, the use of certain medications included in combination ART regimens have been also 
shown to contribute to the development of diabetes in people living with HIV [14]. In this regard, a recent metaanalysis of data from 41 observational studies reported that the risk of diabetes among ART-exposed patients was as four times higher compared with treatment-naive patients, and have suggested that ART may potentially be the single most consistent determinant of diabetes in people living with HIV [15].

Although HIV-infected patients on ART are at greater risk of developing diabetes and thus, suffer extra morbidity and mortality than those without the disease; relatively little is known about its burden among HIV infected patients in Ethiopia. The aim of this study was to determine the prevalence of diabetes mellitus and its associated factors among HIV-infected patients in Northeast Ethiopia.

\section{Main texts \\ Methods \\ Study design, settings and participants}

This cross-sectional study was conducted from January to May 2018 at the ART clinic of Dessie Referral Hospital (DRH), Northeast Ethiopia. DRH is found in Dessie town of Amhara regional state, which is located $401 \mathrm{~km}$ northeast of the capital Addis Ababa, Ethiopia. The hospital serves as a referral center for the Wollo and surrounding zones and provides HIV/AIDS interventions including free diagnosis, treatment and monitoring. HIV-infected adults (aged $>18$ years) attending the ART outpatient clinic for regular follow up, who were on ART for at least 12 months and willing to provide consent were included in the study. Patients were excluded if they were pregnant (women), hospitalized, with a clinical thyroid disease and/or with critical illness that rendered them unable to answer the questionnaires.

\section{Sample size determination}

The sample size was calculated by considering $50 \%$ prevalence rate of diabetes mellitus. Using single population proportion formula, with the following parameters: $\mathrm{Z}=$ the level of statistical significance with a 95\% confidence interval $(\mathrm{CI})$ of 1.96 , and a precision level of 0.05 then the minimum sample size obtained was 384 . By adding $10 \%$ to account for non-respondents, a total of $422 \mathrm{HIV}$ infected individuals on ART were consecutively included in the study.

\section{Data collection and laboratory measurements}

Participants were interviewed for collecting data on socio-demographic, medical and family history, and behavioral factors (smoking and alcohol consumption) by using a pre-tested structured questionnaire. During the interview process, patients were given an ID number and then had their anthropometric data such as weight $(\mathrm{kg})$, height $(\mathrm{m})$, and blood pressure $(\mathrm{mmHg})$ collected. The body mass index (BMI) was calculated as weight $(\mathrm{kg})$ divided by the square of height (meters). Blood pressure (BP) was measured using a manual sphygmomanometer in a sitting position after $5 \mathrm{~min}$ at rest and three measurements were averaged to be recorded. Clinical measures including duration of HIV infection, duration on ART, types of ART-regimens were abstracted from patients' database. Blood samples were collected in the early morning after an overnight fasting. Fasting plasma glucose was measured by enzymatic GOD-PAP method as $\mathrm{mg} / \mathrm{dl}$ using A25 Biosystems clinical chemistry analyzer (BioSystems S.A., Barcelona, Spain). CD4 cell count was measured using the BD FACSCOUNT system (Becton Dickenson and Company, California, USA).

\section{Definitions}

Diabetes mellitus was defined as fasting plasma glucose level $\geq 126 \mathrm{mg} / \mathrm{dl}$ on two consecutive study visits [16] and/or a previous diagnosis of diabetes. Hypertension was defined as self-reported use of antihypertensive medication and/or systolic $\mathrm{BP} \geq 140 \mathrm{mmHg}$ and/ or diastolic $\mathrm{BP} \geq 90 \mathrm{mmHg}$ on at least two occasions. Participants were categorized as smokers, if they smoke at least one cigarette for the last 12 months and alcohol consumer, if they consume at least twice weekly of any alcoholic drinks. BMI classified as normal/underweight $\left(\mathrm{BMI}<25 \mathrm{~kg} / \mathrm{m}^{2}\right.$ ), overweight (BMI $\left.25-29.9 \mathrm{~kg} / \mathrm{m}^{2}\right)$ and obese $\left(B M I \geq 30 \mathrm{~kg} / \mathrm{m}^{2}\right)$.

\section{Statistical analysis}

Data were entered into "EpiData version 3.1" and exported to SPSS version 20.0 statistical software for analysis. Data were reported using mean \pm standard deviation (SD) for continuous variables and proportions for categorical variables. Comparisons between groups were done by Chi square $\left(\mathrm{X}^{2}\right)$ test or $t$ test as appropriate. Variables having $P$-value $<0.25$ in the univariate analysis were included in the multivariate model using logistic regression and the corresponding adjusted odds ratios (AOR) and 95\% confidence intervals (CI) were used to identify factors independently associated with diabetes. $P$ value $<0.05$ was used to indicate statistical significance.

\section{Ethical consideration}

Study protocol was approved by the Institutional Review Board of College of Medicine and Health Sciences of Wollo University. Permission to conduct the study was also obtained from Dessie Referral Hospital. An informed verbal as well as written consent was obtained from all the patients enrolled. Physicians were informed about diabetic patients for proper management. 


\section{Results}

\section{Demographic and clinical characteristics of the study} participants

Of the total $422 \mathrm{HIV}$ infected patients considered eligible, 408 (66.9\% females and $33.1 \%$ males) were included in the analysis. The participants' demographic and clinical characteristics are presented on Table 1. The mean age was $37 \pm 10.3$ years, ranging from 18 to 73 years. One hundred and fifty (36.8\%) participants were receiving AZT containing ART regimens $(\mathrm{AZT}+3 \mathrm{TC}+\mathrm{EFV} /$ NVP) (Table 1).

\section{Prevalence of diabetes and associated factors}

A total of $36(8.8 \%)$ patients had diabetes and 61 (15.0\%) had a fasting plasma glucose $111-125 \mathrm{mg} / \mathrm{dl}$. Of the patients with diabetes, 14 (3.9\%) knew about their diabetes status. Diabetes prevalence increased significantly with age of the patients, $4.7 \%$ for age $18-34$ years, $6.8 \%$ for $35-45$ years and $21.8 \%$ for $>45$ years, and was significantly higher in older patients (aged $>45$ years): $21.8 \%$ vs. $5.8 \%(P<0.001)$. The prevalence was slightly higher in men $(11.9 \%)$ than women $(7.3 \% ; P=0.129)$. No significant difference was also detected in diabetes prevalence between rural (10.2\%) and urban residents (8.4\%; $P=0.600)$.

Diabetes prevalence was significantly higher in participants with less than high school education $(P=0.039)$, longer duration since HIV diagnoses $(P=0.035)$, longer duration on ART $(P=0.002)$, a family history of diabetes $(P=0.005)$, hypertension $(P=0.005)$ and $\mathrm{HCV}$ co-infection $(P=0.013)$. However, there was no difference between the two groups with respect to alcohol use $(P=0.105)$, smoking $(P=0.597)$, BMI $(P=0.105)$, CD4 cell count $(P=0.207)$, and types of ART $(P=0.659)$ (Table 2).

In multivariate logistic analysis, older age (> 45 years; $\mathrm{AOR}=3.51$, 95\% CI 1.52-8.10, $P=0.003)$, longer duration on ART $(\mathrm{AOR}=2.67,95 \%$ CI 1.16-6.17, $P=0.021)$, a family history of diabetes $(\mathrm{AOR}=6.46,95 \% \mathrm{CI} 3.36-$ $21.29, P<0.001)$, and hypertension $(\mathrm{AOR}=2.62,95 \% \mathrm{CI}$ $1.20-5.72, P=0.016)$ were independently associated with increased risk of diabetes (Table 3 ).

\section{Discussion}

In this study, we found a high prevalence of diabetes (8.8\%) among patients living with HIV on ART attending our clinic in Northeast Ethiopia. The prevalence estimate of diabetes in this study was comparable to 8.5\% prevalence reported from Jimma University Specialized Hospital, Southwest Ethiopia [17] and 8\% from Wolayta Sodo hospital, Southern Ethiopia [18], but higher than the $5.1 \%$ prevalence reported from
Table 1 Demographic and clinical characteristics of study participants $(n=408)$

\begin{tabular}{|c|c|}
\hline Characteristics & \\
\hline Age (year), mean $\pm S D$ & $37 \pm 10.3$ \\
\hline \multicolumn{2}{|l|}{ Age group, $n(\%)$} \\
\hline $18-34$ & $169(41.4)$ \\
\hline $35-45$ & $161(39.5)$ \\
\hline$>45$ & $78(19.1)$ \\
\hline \multicolumn{2}{|l|}{ Sex, n (\%) } \\
\hline Male & $135(33.1)$ \\
\hline Female & $273(66.9)$ \\
\hline \multicolumn{2}{|l|}{ Residence, n (\%) } \\
\hline Rural & $88(21.6)$ \\
\hline Urban & $320(78.4)$ \\
\hline \multicolumn{2}{|l|}{ Education, n (\%) } \\
\hline$<$ High school & $240(58.8)$ \\
\hline$\geq$ High school & $168(41.2)$ \\
\hline \multicolumn{2}{|l|}{ Duration of infection, $\mathrm{n}(\%)$} \\
\hline$\leq 5$ years & $227(55.6)$ \\
\hline$>5$ years & $181(44.4)$ \\
\hline \multicolumn{2}{|l|}{ Duration on ART, n (\%) } \\
\hline$\leq 5$ years & $145(35.5)$ \\
\hline$>5$ years & $263(64.5)$ \\
\hline \multicolumn{2}{|l|}{ ART regimen, $\mathrm{n}(\%)$} \\
\hline $\mathrm{AZT}+3 \mathrm{TC}+\mathrm{EFV}$ & $66(16.2)$ \\
\hline$T D F+3 T C+N V P$ & $71(17.4)$ \\
\hline$A Z T+3 T C+N V P$ & $84(20.6)$ \\
\hline $\mathrm{TDF}+3 \mathrm{TC}+\mathrm{EFV}$ & $76(18.6)$ \\
\hline Other & $111(27.2)$ \\
\hline Current smoker, n (\%) & $16(3.9)$ \\
\hline Alcohol consumers, n (\%) & $62(15.2)$ \\
\hline Family history of DM, n (\%) & 42 (10.3). \\
\hline Body mass index $\left(\mathrm{kg} / \mathrm{m}^{2}\right)$, mean $\pm S D$ & $20.40 \pm 2.11$ \\
\hline Systolic BP (mmHg), mean \pm SD & $127.2 \pm 12.8$ \\
\hline Diastolic BP (mmHg), mean \pm SD & $82.0 \pm 6.0$ \\
\hline Hypertension, n (\%) & $121(29.7)$ \\
\hline $\mathrm{CD} 4$ count $\left(\right.$ cell $\left./ \mathrm{mm}^{3}\right)$, mean $\pm \mathrm{SD}$ & $343.1 \pm 311.6$ \\
\hline Fasting plasma glucose $(\mathrm{mg} / \mathrm{dl})$, mean $\pm \mathrm{SD}$ & $105.7 \pm 39.0$ \\
\hline
\end{tabular}

Other regimens: $\mathrm{D} 4 \mathrm{~T}+3 \mathrm{TC}+\mathrm{NVP}, \mathrm{D} 4 \mathrm{~T}+3 \mathrm{TC}+\mathrm{EFV}, \mathrm{TDF}+3 \mathrm{TC}+\mathrm{ATV} / \mathrm{R}$,

$\mathrm{ABC}+3 \mathrm{TC}+\mathrm{ATV} / \mathrm{R}, \mathrm{ABC}+3 \mathrm{TC}+\mathrm{EFV}, \mathrm{AZT}+3 \mathrm{TC}+\mathrm{ATV} / \mathrm{R}, \mathrm{DDI}+\mathrm{ABC}+\mathrm{ATV} / \mathrm{R}$

University of Gondar Hospital, Northwest Ethiopia [19] and $6.9 \%$ from Tikur Anbessa Specialized hospital in Addis Ababa, Ethiopia [20]. Our prevalence estimate of diabetes was also higher than those reported in studies conducted in other countries, including $4.0 \%$ from ART clinic of Uganda [21], 4.1\% and 6.6\% from Malawi $[22,23]$ and $5.0 \%$ from Zambia [24], but lower than the $14.5 \%$ prevalence reported from Senegal [25] and $18.0 \%$ from Tanzania [26]. The observed difference could be due to variation in the lifestyle and ART regimens or 
Table 2 Prevalence of diabetes among HIV-infected patients on ART at DRH in Northeast Ethiopia

\begin{tabular}{|c|c|c|c|}
\hline Characteristics & Diabetes, n (\%) & No diabetes, n (\%) & $P$-value \\
\hline Age (years) & & & $<0.001$ \\
\hline$\leq 45$ & $19(5.8)$ & $311(94.2)$ & \\
\hline$>45$ & $17(21.8)$ & $61(78.2)$ & \\
\hline Sex & & & 0.129 \\
\hline Male & $16(11.9)$ & $119(88.1)$ & \\
\hline Female & $20(7.3)$ & $253(92.7)$ & \\
\hline Residence & & & 0.600 \\
\hline Rural & $9(10.2)$ & 79 (89.8) & \\
\hline Urban & $27(8.4)$ & $293(91.6)$ & \\
\hline Education & & & 0.039 \\
\hline$<$ High school & $27(11.2)$ & $213(88.8)$ & \\
\hline$\geq$ High school & $9(5.4)$ & $159(94.6)$ & \\
\hline Duration of infection (years) & & & 0.035 \\
\hline$\leq 5$ & $7(4.8)$ & $138(95.2)$ & \\
\hline$>5$ & $29(11.0)$ & $234(89.0)$ & \\
\hline Duration on ART (years) & & & 0.002 \\
\hline$\leq 5$ & $11(4.8)$ & $216(95.2)$ & \\
\hline$>5$ & $25(13.8)$ & $156(86.2)$ & \\
\hline ART regimen & & & 0.659 \\
\hline $\mathrm{AZT}+3 \mathrm{TC}+\mathrm{EFV}$ & $6(9.1)$ & $60(90.9)$ & \\
\hline $\mathrm{TDF}+3 \mathrm{TC}+\mathrm{NVP}$ & $3(4.2)$ & $68(95.8)$ & \\
\hline$A Z T+3 T C+N V P$ & $9(10.7)$ & $75(89.3)$ & \\
\hline $\mathrm{TDF}+3 \mathrm{TC}+\mathrm{EFV}$ & $7(9.2)$ & $69(90.8)$ & \\
\hline Other & $11(9.9)$ & $100(90.1)$ & \\
\hline Smoking & & & 0.597 \\
\hline Yes & $2(12.5)$ & $14(87.5)$ & \\
\hline No & $34(8.7)$ & $358(91.3)$ & \\
\hline Family history diabetes & & & $<0.001$ \\
\hline Yes & $12(28.6)$ & $30(71.4)$ & \\
\hline No & $24(6.6)$ & $342(93.4)$ & \\
\hline Body mass index $\left(\mathrm{kg} / \mathrm{m}^{2}\right)$ & & & 0.397 \\
\hline$<25$ (Normal/underweight) & $34(8.6)$ & $361(91.4)$ & \\
\hline$\geq 25$ (Overweight/obesity) & $2(15.4)$ & $11(84.6)$ & \\
\hline Hypertension & & & 0.001 \\
\hline Yes & $19(17.7)$ & $102(84.3)$ & \\
\hline No & $17(5.9)$ & $270(94.1)$ & \\
\hline CD4 count (cell/mm³) & & & 0.207 \\
\hline$\leq 350$ & $19(7.5)$ & $236(92.5)$ & \\
\hline$>350$ & $17(11.1)$ & $136(88.9)$ & \\
\hline HCV co-infection & & & 0.013 \\
\hline Yes & $2(40.0)$ & $3(60.0)$ & \\
\hline No & $34(8.4)$ & $369(91.6)$ & \\
\hline
\end{tabular}

due to variation in the age distribution of the studied subjects.

Consistent with previous studies $[14,17,25,27,28]$, we found an increased risk of diabetes among older patients with HIV on combination ART. Age as a traditional risk factor plays an important role in the development of diabetes among HIV-infected patients, and with increased survival of infected patients treated with combination ART, a rise in diabetes incidence independent of HIV-related influences may occur with ageing of this 
Table 3 Factors associated with diabetes among HIV-infected patients on ART at DRH in Northeast Ethiopia

\begin{tabular}{|c|c|c|c|c|}
\hline Characteristics & Unadjusted OR $(95 \% \mathrm{Cl})$ & $P$-value & Adjusted OR (95\% Cl) & $P$-value \\
\hline \multicolumn{5}{|l|}{ Age (years) } \\
\hline$>45$ & $4.56(2.24-9.27)$ & $<0.001$ & $3.51(1.52-8.10)$ & 0.003 \\
\hline$\leq 45$ & 1.00 & & 1.00 & \\
\hline \multicolumn{5}{|l|}{ Education } \\
\hline$<$ High school & $2.24(10.3-4.89)$ & 0.039 & $2.11(0.92-4.86)$ & 0.079 \\
\hline$\geq$ High school & 1.00 & & 1.00 & \\
\hline \multicolumn{5}{|c|}{ Duration of infection (years) } \\
\hline$>5$ & $2.44(1.04-5.73)$ & 0.035 & $1.86(0.68-5.07)$ & 0.226 \\
\hline$\leq 5$ & 1.00 & & 1.00 & \\
\hline \multicolumn{5}{|c|}{ Duration on ART (years) } \\
\hline$>5$ & $3.15(1.50-6.59)$ & 0.002 & $2.67(1.16-6.17)$ & 0.021 \\
\hline$\leq 5$ & 1.00 & & 1.00 & \\
\hline \multicolumn{5}{|c|}{ Family history diabetes } \\
\hline Yes & $5.70(2.60-12.52)$ & $<0.001$ & $6.46(3.36-21.29)$ & $<0.001$ \\
\hline No & 1.00 & & 1.00 & \\
\hline \multicolumn{5}{|l|}{ Hypertension } \\
\hline Yes & $2.61(1.31-5.22)$ & 0.001 & $2.62(1.20-5.72)$ & 0.016 \\
\hline No & 1.00 & & 1.00 & \\
\hline \multicolumn{5}{|l|}{ HCV co-infection } \\
\hline Yes & $4.74(1.17-44.81)$ & 0.013 & $6.49(0.82-51.09)$ & 0.076 \\
\hline No & 1.00 & & 1.00 & \\
\hline
\end{tabular}

population [29, 30]. A family history of diabetes was one of the factors found to be independently associated with increased risk of prevalent diabetes. In the present study, $10.3 \%$ of our HIV-infected patients were with a family history of diabetes and they did have a significantly increased risk of diabetes. This was not surprising and is in agreement with previous findings, which demonstrated the higher risk of diabetes among HIV-infected persons who had a family history of diabetes [31, 32].

Our results showed that duration of ART use, but not HIV infection, was associated with an increased risk of diabetes. This was consistent with the results of related studies [17, 25, 33, 34]. Supporting this association, previous follow-up studies have demonstrated induction of insulin resistance and a higher risk of diabetes with the long term use of combination ART [35-37]. Another study has also shown that patients who started ART in early years of the epidemic and had a longer exposure to older ART were at the highest risk of developing diabetes [38]. Targeted screening of diabetes in patients with longer exposure to ART is needed in our setting in order to avoid the associated long-term complications that would otherwise occur.

The present study also found that $29.7 \%$ of the study participants had hypertension, which was comparable to other related studies reporting prevalence estimates ranging from 15.9 to $34.4 \%$ [17, 18, 22, 23, 25].
The present study also found a significant association between hypertension and prevalent diabetes. This was also supported by other previous studies, which showed that hypertension play a significant role in the development of diabetes among HIV-infected patients on ART $[17,19,27]$. Hypertension screening and treatments are therefore needed to reduce the observed contribution to high diabetes risk in this population.

\section{Conclusions}

In conclusion, our study identified a high prevalence of diabetes (8.8\%) among HIV-infected adults attending ART clinic of a hospital in Northeast Ethiopia. Factors such as increased age, family history of diabetes, duration of ART, and hypertension were found to contribute to this high prevalence of diabetes. These findings highlight the need for routine screening and assessment of factors for diabetes in HIV-infected persons receiving combination ART (Additional file 1).

\section{Limitations}

Given the drugs were studied in combinations; we were unable to identify which one contributes to diabetes risk. The other limitation was the cross-sectional nature of the study. The subjective nature of the self-reported response for some items might also be limited by recall bias. Finally, our sampling technique was convenient; 
therefore, our sample cannot be considered representative of all HIV-infected patients receiving treatment in the country. However, the study has provided some data to inform decision-makers to improve current care and management of HIV-infected persons on ART.

\section{Additional file}

Additional file 1. Questioner used in the study.

\section{Abbreviations}

AOR: adjusted odds ratio; ART: antiretroviral therapy; BMI: body mass index; BP: blood pressure; Cl: confidence interval; DRH: Dessie Referral Hospital; HCV: hepatitis $C$ virus; HIV: human immunodeficiency virus.

\section{Acknowledgements}

The authors would like to acknowledge data collectors, and staff of ART clinic of Dessie Referral Hospital for collecting the data.

\section{Authors' contributions}

TF and AG were involved in the conception, design, analysis, interpretation, report writing and manuscript writing. Both authors read and approved the final manuscript.

\section{Funding}

The study was funded by Wollo University. The funders had no role in study design, data collection and analysis, decision to publish, or preparation of the manuscript.

\section{Availability of data and materials}

The datasets generated and/or analysed during this study are not publicly available due to presence of sensitive (confidential) participants' information and additional data than that used in this publication. But data are available from the corresponding author on reasonable request.

\section{Ethics approval and consent to participate}

The study protocol was approved by the Institutional Review Board of College of Medicine and Health Sciences, Wollo University. Permission to conduct the study was also obtained from Dessie Referral Hospital Administration. All participants provided verbal as well as written informed consent prior to study entry. Confidentiality was assured for all the information provided and personal identifiers were not included on questionnaire.

\section{Consent to publish}

Not applicable.

\section{Competing interests}

The authors declare that they have no competing interests.

Received: 2 May 2019 Accepted: 24 June 2019

Published online: 01 July 2019

\section{References}

1. UNAIDS. Global HIV \& AIDS statistics-2018 fact sheet. http://www.unaid s.org/en/resources/fact-sheet.

2. Yang $\mathrm{C}-\mathrm{H}$, Huang Y-F, Hsiao C-F, Yeh Y-L, Liou H-R, Hung C-C, et al. Trends of mortality and causes of death among HIV-infected patients in Taiwan, 1984-2005. HIV Med. 2008;9:535-43.

3. Mills EJ, Bakanda C, Birungi J, Chan K, Ford N, Cooper CL, et al. Life expectancy of persons receiving combination antiretroviral therapy in low-income countries: a cohort analysis from Uganda. Ann Intern Med. 2011;155:209-16.
4. Samji H, Cescon A, Hogg RS, Modur SP, Althoff KN, Buchacz K, et al. Closing the Gap: increases in life expectancy among treated HIV-positive individuals in the United States and Canada. PLoS ONE. 2013;8(12):e81355.

5. Guaraldi G, Orlando G, Zona S, Menozzi M, Carli F, Garlassi E, et al. Premature age-related comorbidities among HIV-infected persons compared with the general population. Clin Infect Dis. 2011;53(11):1120-6.

6. Chhoun P, Ngin C, Tuot S, Pal K, Steel M, Dionisio J, et al. Non-communicable diseases and related risk behaviors among men and women living with HIV in Cambodia: findings from a cross-sectional study. Int J Equity Health. 2017;16:125

7. Monroe AK, Glesby MJ, Brown TT. Diagnosing and managing diabetes in HIV-infected patients: current concepts. Clin Infect Dis. 2015;60(3):453-62.

8. Akgün KM, Gordon K, Pisani M, Fried T, McGinnis KA, Tate JP, et al. Risk factors for hospitalization and medical Intensive care unit (MICU) admission among HIV-infected veterans. J Acquir Immune Defic Syndr. 2013;62:52-9.

9. Medapalli R, Parikh CR, Gordon K, Brown ST, Butt AA, Gibert CL, et al. Comorbid diabetes and the risk of progressive chronic kidney disease in HIV-infected adults: data from the Veterans Aging Cohort Study. J Acquir Immune Defic Syndr. 2012;60(4):393-9.

10. Jotwani V, Li Y, Grunfeld C, Choi Al, Shlipak MG. Risk factors for ESRD in HIV-Infected Individuals: traditional and HIV-related factors. Am J Kidney Dis. 2012;59(5):628-35.

11. Brown TT, Cole SR, Li X, Kingsley LA, Palella FJ, Riddler SA, et al. Antiretroviral therapy and the prevalence and incidence of diabetes mellitus in the multicenter AIDS cohort study. Arch Intern Med. 2005;165:1179-84.

12. Hernandez-Romieu AC, Garg S, Rosenberg ES, Thompson-Paul AM, Skarbinski J. Is diabetes prevalence higher among HIV-infected individuals compared with the general population? Evidence from MMP and NHANES 2009-2010. BMJ Open Diabetes Res Care. 2017;5:e000304.

13. Kalra S, Kalra B, Agrawal N, Unnikrishnan A. Understanding diabetes in patients with HIV/AIDS. Diabetol Metab Syndr. 2011;3:2.

14. Capeau J, Bouteloup V, Katlama C, Bastard J-P, Guiyedi V, Salmon-Ceron D, et al. Ten-year diabetes incidence in $1046 \mathrm{HIV}$-infected patients started on a combination antiretroviral treatment. AIDS. 2012;26:303-14.

15. Nduka CU, Stranges S, Kimani PK, Sarki AM, Uthman OA. Is there sufficient evidence for a causal association between antiretroviral therapy and diabetes in HIV-infected patients? A meta-analysis. Diabetes Metab Res Rev. 2017;33:6.

16. WHO. Definition and diagnosis of diabetes mellitus and intermediate hyperglycemia. Geneva: WHO; 2006.

17. Mohammed AE, Shenkute TY, Gebisa WC. Diabetes mellitus and risk factors in human immunodeficiency virus-infected individuals at Jimma University Specialized Hospital, Southwest Ethiopia. Diabetes Metab Syndr Obes Targets Ther. 2015;8:197-206.

18. Sachithananthan V, Loha E, Gose M. Prevalence of diabetes mellitus, hypertension and lipodystrophy in HAART receiving HIV patients in Southern Ethiopia. Int STD Res Rev. 2013;1:1-11.

19. Abebe SM, Getachew A, Fasika S, Bayisa M, Demisse AG, Mesfin N. Diabetes mellitus among HIV-infected individuals in follow-up care at University of Gondar Hospital, Northwest Ethiopia. BMJ Open. 2016;6:e011175.

20. Feleke Y, Fekade D, Mezegebu Y. Prevalence of highly active antiretroviral therapy associated metabolic abnormalities and lipodystrophy in HIV infected patients. Ethiop Med J. 2012;50(3):221-30.

21. Omech B, Sempa J, Castelnuovo B, Opio K, Otim M, Harriet MayanjaKizza, et al. Prevalence of HIV-associated metabolic abnormalities among patients taking first-line antiretroviral therapy in Uganda. ISRN AIDS. 2012;2012:1-6.

22. Divala $\mathrm{OH}$, Amberbir A, Ismail Z, Beyene T, Garone D, Pfaff C, et al. The burden of hypertension, diabetes mellitus, and cardiovascular risk factors among adult Malawians in HIV care: consequences for integrated services. BMC Public Health. 2016;16:1243.

23. Rucker SCM, Alia T, Bitilinyu-Bangoh J, Bermudez-Aza EH, Salumu L, Quiles IA, et al. High rates of hypertension, diabetes, elevated low-density lipoprotein cholesterol, and cardiovascular disease risk factors in HIV-infected patients in Malawi. AIDS. 2018;32:253-60.

24. Shankalala P, Jacobs C, Bosomprah S, Vinikoor M, Katayamoyo P, Michelo C. Risk factors for impaired fasting glucose or diabetes among HIV infected patients on ART in the Copperbelt Province of Zambia. J Diabetes Metab Disord. 2017;16:29. 
25. Diouf A, Cournil A, Ba-Fall K, Ngom-Gueye NF, Eymard-Duvernay S, Ndiaye I, et al. Diabetes and hypertension among patients receiving antiretroviral treatment since 1998 in Senegal: prevalence and associated factors. ISRN AIDS. 2012;2012:1-8.

26. Maganga E, Smart LR, Kalluvya S, Kataraihya JB, Saleh AM, Obeid L, et al. Glucose metabolism disorders, HIV and antiretroviral therapy among tanzanian adults. PLoS ONE. 2015;10(8):e0134410.

27. Tripathi A, Liese AD, Jerrell JM, Zhang J, Rizvi AA, Albrecht H, et al. Incidence of diabetes mellitus in a population-based cohort of HIV-infected and non-HIV-infected persons: the impact of clinical and therapeutic factors over time. Diabet Med. 2014;31:1185-93.

28. Ledergerber B, Furrer H, Rickenbach M, Lehmann R, Elzi L, Hirschel B, et al. Factors associated with the incidence of type 2 diabetes mellitus in HIV-infected participants in the swiss HIV cohort study. Clin Infect Dis. 2007:45:111-9.

29. Butt AA, McGinnis K, Rodriguez-Barradas MC, Crystal S, Simberkoff M, Goetz MB, et al. HIV infection and the risk of diabetes mellitus. AIDS. 2009;23(40):1227-34.

30. Samaras K. The burden of diabetes and hyperlipidemia in treated HIV infection and approaches for cardiometabolic care. Curr HIVAIDS Rep. 2012;9:206-17.

31. Yoon C, Gulick RM, Hoover DR, Vaamonde CM, Glesby MJ. Case-control study of diabetes mellitus in HIV-infected patients. J Acquir Immune Defic Syndr. 2004;37:1464-9.

32. Lo Y-C, Chen M-Y, Sheng W-H, Hsieh S-M, Sun H-Y, Liu W-C, et al. Risk factors for incident diabetes mellitus among HIV-infected patients receiving combination antiretroviral therapy in Taiwan: a case-control study. HIV Med. 2009;10:302-9.
33. Abrahams Z, Dave JA, Maartens G, Levitt NS. Changes in blood pressure, glucose levels, insulin secretion and anthropometry after long term exposure to antiretroviral therapy in South African women. AIDS Res Ther. 2015;12:24

34. Calza L, Masetti G, Piergentili B, Trapani F, Cascavilla A, Manfredi R, et al. Prevalence of diabetes mellitus, hyperinsulinaemia and metabolic syndrome among 755 adult patients with HIV-1 infection. Int J STD AIDS. 2011;22:43-5

35. Tien PC, Schneider MF, Cole SR, Levine AM, Cohen M, DeHovitz J, et al. Antiretroviral therapy exposure and incidence of diabetes mellitus in the Women's Interagency HIV Study. AIDS. 2007;21(13):1739-45.

36. Tien PC, Schneider MF, Cole SR, Levine AM, Cohen M, DeHovitz J, et al. Antiretroviral therapy exposure and insulin resistance in the women's interagency HIV study. Acquir Immune Defic Syndr. 2008;49(4):369-76.

37. Brown TT, Li X, Cole SR, Kingsley LA, Palella FJ, Riddler SA, et al. Cumulative exposure to nucleoside analogue reverse transcriptase inhibitors is associated with insulin resistance markers in the Multicenter AIDS Cohort Study. AIDS. 2005;19:1375-83.

38. Samad F, Harris M, Puskas CM, Ye M, Chia J, Chacko S, et al. Incidence of diabetes mellitus and factors associated with its development in HIV-positive patients over the age of 50. BMJ Open Diab Res Care. 2017; 5:e000457.

\section{Publisher's Note}

Springer Nature remains neutral with regard to jurisdictional claims in published maps and institutional affiliations.
Ready to submit your research? Choose BMC and benefit from:

- fast, convenient online submission

- thorough peer review by experienced researchers in your field

- rapid publication on acceptance

- support for research data, including large and complex data types

- gold Open Access which fosters wider collaboration and increased citations

- maximum visibility for your research: over $100 \mathrm{M}$ website views per year

At BMC, research is always in progress.

Learn more biomedcentral.com/submissions 